\title{
Personal Factors Affecting Consumer Purchase Decision towards Men Skin Care Products - A Study in Ho Chi Minh City, Vietnam
}

\author{
Mai Ngoc Khuong and Hoang Thi My Duyen
}

\begin{abstract}
This study examined some depth the influences of skin's health care, body attraction, age and aging process, selfimage, cognition of using men skin care products to male customer purchase decision of skin care products in Ho Chi Minh City, Viet Nam. Quantitative approach was mainly used with questionnaire developed and distributed to 313 men in the age between 20-50 years old in HCM City. This study found that higher levels of skin's health attention, body attraction, age and aging process, self-image, and cognition of using men skin care products would likely purchase more of men skin care products. In addition, the empirical results indicated that four personal factors of self-image, skin's health attention, body attraction, and age and aging process had significant effects on male consumer purchase decision.
\end{abstract}

Index Terms-Men skin care, personal factors, consumer purchase decision, Vietnamese skin care products market.

\section{INTRODUCTION}

In the globalization era, improvement of technology, science, society, economy and education provide people to with better standard of living and styles. Relating to the development of purchasing power in consumers and market trend that people become more conscious of hygiene and beauty [1], it affects to the rapid growth in beauty care industry, especially in this decade. Cosmetics market in the world, especially the professional skin care has emerged stronger thanks to the increasing demand of customers, especially for the skin care brand, health sector development strongly grew in 2011. Most of people would like to be beautiful, healthy and good looking. There is a normal fact that most people want to look like the models. Men and women are alike, a smooth and bright skin with an ideal body shape for a wonderful life [2]. Not only women need beauty care, men should be increasingly cared more for themselves. Today, with the unpredictable changes of weather, everyone needs a cosmetic capable of protecting their skin to avoid the impact of the environment. Especially men, who are exposed to harsh external environment frequently, the more necessary the use of cosmetic skin care.

The beauty industry for women has been obviously growing since long times ago whereas the men's market

Manuscript received July 20, 2015; revised March 16, 2016

Mai Ngoc Khuong and Hoang Thi My Duyen are with the School of Business, International University - VNU-HCM, Vietnam (e-mail: mnkhuong@hcmiu.edu.vn, rileylv193@gmail.com). have just become blooming in men aspects lately. In recent years, Vietnam is heavily influenced by trends of beauty in the world, the concept of male beauty has gradually changed. Currently men are more aware of their body and the demand for beautifulness, aesthetics, youthfulness, healthiness, and thinness which drag them away from old opinion about "only sanitation". Men pay more attention to their appearance, are more interested in cosmetics. Nevertheless, even though men buy more beauty products as grooming and skin care products, it is predicted that these products are still bought approximately $80 \%$ by their wives or companions [3]. As a result, the percentage drive us to study if there is any internal or external reasons which can be factors affect men purchasing of these kinds of skin care products, just because men do not have many experiences against the products, or there is any masculine issue involvement. In general, some fear to buy these kinds of products directly can lead into question their virility, associating them to a female, effeminate or homosexual universe.

Cosmetics men despite widely popular in foreign countries, but remains an area of research is quite new to Vietnam. Development potential of the market is huge, but there is a lack of study focusing on male subjects in Vietnam. So there should be a study in details of which individual elements of the men affect their purchase decisions of cosmetics. From this practice, the research tried to find out the personal factors affecting purchase decision of male skin care products.

\section{LITERATURE REVIEW}

\section{A. Consumer Purchase Decision}

Currently, there are many different definitions of purchase decision consumer. According to [4], purchase decision consumer is behaviours showed by decisionmaking units in the buying, usage and disposal of goods and services. Purchase decision consumer is the decisionmaking process and physical activity individuals engage in when evaluating, acquiring, using or disposing of goods and services [5]. [6] argued that consumer behavior is the behavior that consumers expose in searching for purchasing, using, evaluating and disposing of product, service and idea which they expect, will fulfill their requirements. Besides that, [7] defines the consumer behavior's main factors and performs the interaction of Environmental Factors (including marketing stimuli (MIX) and environmental stimuli), Buyer's Black Box (including Buyers 
Characteristics and decision process) and finally Buyer's Response. In addition, [8] identified that purchase decision consumer is activities directly related to obtaining, consuming, and disposing of products and services, including the decision processes that precede and follow these actions. In services require time (holiday, travel, etc.), decisions are forming important part of consumer behaviour. One notice thing is that purchase decision does not finish with purchase of goods or services, but also post purchase activities are consisted of consumer behavior.

This research considers about the meaning of Engal, Blackwell \& Miniard with consumer decision-process model [8]. Thus, purchase decision consumer includes three main actions: purchase, consumption, disposal cargo handling services. Consumer decision is the active factor of competitive theories. Several researches can be identified as center to the job and worldview of behavioral economists and other behavior analysis. [9] claims that the behaviorenvironment relationships observed by psychologists can be known as economic in market.

The research of consumer decision for any product is important to marketers in forming the properties of their organizations. It is vital for controlling consumption of goods and maintaining market stability. In addition, it is helpful in growing ways for the more efficient utilization of resources in marketing. It also helps in solving marketing management challenges in more effective way.

The development of consumer protection movement has made an urgent demand to understand how consumers create their consumption and purchasing decision. Consumers' tastes and favourites are rapid changing. In conclusion, consumer behavior helps in constructing of production policy. For effective market segmentation and target marketing, it is important to have knowledge of consumers and their purchase decision.

According to [1], the study showed three groups of variables that affect the consumer of male cosmetics, based on the first research hypothesis is skin care products has been affected by sex or not. This study focuses on the attitudes and behaviors of men who buy beauty products shows that there is a group of variables that affect consumer behavior of male skin care products, the author has a set of variables into three main groups. The first group can be called individual variables, including self-image, the influence of age, health status, and the appeal of the body. Group 2 is the socio-cultural variables, including beliefs and lifestyle. The last group can be regarded as the marketing variables, such as advertising or purchase situations. [10] claimed that both level elements (individualismcollectivism) and individual cultural disparity factors (independent and interdependent self-concept) systematically effect impulsive buying behavior. In another study, the different elements that push buyers to purchase products were discussed studied by [11] those are mainly: personal factors, situational factors, the reason for the consumer's purchase and societal factors. Therefore, knowing the elements that impact the purchasing behavior could rise the sales volume.

However, in my study, it just research about personal factors affecting purchase decision consumer on men skin care products.

\section{B. Personal Factors}

According to [12], personal factors are characteristics that are specific to a person and may not relate to other people within the same group. These characteristics may include how a person makes decisions, their unique habits and interests, and opinions. When considering personal factors, decisions are also influenced by age, gender, background, culture, and other personal issues. For example, an older person will likely exhibit different consumer behaviors than a younger person, meaning they will choose products differently and spent their money on items that may not interest a younger generation. This study will concentrate to personal factors that affect to purchase decision consumer. It will focus on five factors that are: skin's health attention, body attraction, cognition, age and aging, self-image and cognition of using men skin care products.

\section{Skin's Health Attention}

The skin can tell a lot about your health. If you pay more attention, it can be a dominant early-warning system for a range of concerns about health problems [13]. Male are typically out in the factors more than female, their skin are more affected by UV rays, environmental pollution, wind damage, and other factors that all work together to harm the skin, creating more wrinkles and hyperpigmentation.

First, men need to be cared about their health. Men can be using sunscreen, in addition, they need moisturizers that are fulfilled with protective antioxidants. Protection against skin cancer is the best reason to think about using skin care and to regularly test your skin for any suspicious moles or other injuries.

Many men who work in outside workplaces, such as ranchers, construction workers, and truckers, are more deal with the sun, wind, and other elements that can directly produce painful conditions on the skin. Truckers may have one side of the face more harmed than the other, because of the sun from the window. Constructions workers may bear from extreme dryness, daftness, and even cracking and bleeding. Solving these skin problems can create going back to work the next day just a little bit easier.

In recent days, good-looking seems to matter more than ever. Looking "healthy" is especially advantages for many workers, and having smooth skin is one of the most observable ways to perform good health.

\section{Body Attraction}

Odors can elicit a range of emotions, and even trigger memories, allowing us to reminisce as the aromas stimulate our senses. When it comes to body attraction, we can sniff out our perfect match not by the deodorants, or perfumes they use, but by the body odor we find most attractive, masked under those chemicals. According to a recent study published in the American Journal of Political Science, our natural body odor can be a sign of fit to potential partners, as it is more awaken by the smell of people with shared political ideas, not opposing ideas [14], [15].

Nowadays, nobody is saying that looks aren't an important part of attraction. However, men with the nice face and the muscular body are not attractive women surely. According to a 2012 study, male with a healthy skin are more attractive to female than those with a manly face. 
Moreover, good appearance women and men earn 4 to 5 percent more money than their less attractive partners and get more notice from their employers, says a Newsweek study [16]. Good-looking men earn, on average, 5 percent more than their less-attractive partners, says the magazine, while attractive women create 4 percent more. [16]. Meanwhile, the less attractive you are in America, the more likely you are to be poor, achieve a lower wage and worse performance reviews at work [16]. And unattractive people will be alone who are also statistically less likely to be married [16].

So, the body attraction is very necessary to men in love and career. The tendencies are changing with the preparation habits of today's modern man. The motivation is that people are much more cognition of their appearances and want to be more attractive and appealing. Therefore, men have the trend to choose the skin care products to become more attractive which plays an important role for their success.

\section{E. Age and Aging Process}

Consumers have different needs and want if they are in different age groups. People also change the good and services they buy over the change of their habits and life. Tastes in food, clothes, furniture and recreation are often age combined. Purchasing is also formed by family life cycle - the phase through which families can pass as they mature over time [17]. In skin care products market, young generation tend to be easier to deal with skin care products than old generation.

The age stays a vital factor in consumption, especially in the beauty industry. With regard to age, [18] indicated that the youths felt important pressure from emotional and social views in their decisions, and the adults and the retired people to a lesser scale. One interpretation of these findings could be that personals lacking in knowledge and experience in certain decision regions, as occurs in the majority of youths, tend to place little value on the elements that affect the decision and are not aware of the decision's complication. In contrast, adults and retired people research these elements more closely and appreciate the quality of their decisions after resolving the appropriate strategies [19]. This claims that adults have developed varied and sophisticated ways to contrast the factors that impact a decision, in accordance also with [20]. Seniors represent a market that needs to be exploited, because they have a vital buying power and they desire to seek a better quality of physical and mental life.

Besides the ageing process of the population in developed countries, people hard and long work and are more easily contrived to unemployment, situation changes, stress, annoyances. Whether it is in private life or in social life, people have to be ready to dismiss back and to respond. In such social configuration, it is very important to take care of ourselves.

\section{F. Self-Image}

According to [21], self-image is the mental image someone has about himself (herself), based on experiences of their lives or on the internalization of others' senses. Selfimages can be very positive, giving a person confidence in their thoughts and activities, or negative, making a person vague of their abilities and ideas.

People tend to buy the products, brands that they feel closer to the image of themselves. In other words, a person can express themselves through the selection of products and brands in accordance with their personal values. Goods are associated with consumers' self-concept because they function as significant material emblems of individual and social identity [22]. Symbolic self-completion theory [23] suggests that conceiving shortcomings in one's self-concept produces a motivation to offset. More recently, such defects have been conceptualized as self-discrepancies between actual self - how a personal sees her/himself - and ideal self - The image that individuals wish to become themselves [24]. Amongst diverse offset strategies, this can relate to acquire and use material emblems which are relevant to those sides of self-felt to be lacking [25]. This study will approach the definition of self-image in terms of the real image, which is measured by the way in which a personal really seen himself (herself).

Customers have a variety of enduring pictures of themselves. These self-images, or cognitions of self, are very closely linked to personality in that personals tend to do purchase products and services and defend retailers whose images or personalities associated to some meaningful way to their own self-images. In principle, customers seek to describe themselves their brand choices and they tend to approach products with images that could exalt their self-concept and avoid those products that do not. Each of us has a "self-image," a perception of how we believe we look to others. According to [26], the behavior allows people to reduce disparities between their actual and ideal self-serve to boost self-esteem. Sometimes consumers wish to change themselves to become a difference or improvement.

Skin care products market encourages and promotes a strong, positive self-image. Even a small change on the outside can create an extraordinary change on the inside, allowing a personal's self-confidence to grow.

\section{G. Cognition on Using Skin Care Products}

In terms of studying consumer behavior, perception is very important to understand which actually affect a consumer's behavior. Cognition is the perception of a person closely related to their behavior. After recognizing the demand to buy something, the consumer's cognition situation would impact the way a person behaves [27]. Different people have different cognitions even for the same object or circumstance since people have their own subjective way to create their cognitions. Cognition is the process of selecting, organizing, and interpreting sensations [28] into information, and stored [29]. Female have been aware of their appearance for long times. They always maintain and take care of their physical image for being attractive and staying competitive in this society. In addition, purchasing and preparing with appearance have been linked to female but now dimming gender roles in society are creating male socially acceptable and it is also acceptable for male to exhibit other womanly characteristics including sensitivity, faith and showing emotions [30].

Today, appearance, image and young-looking are 
becoming more and more important in this society. Many men have turned and concerned on their appearance more than in the past, because not only woman want to be beautiful and young but men also. Men want to feel complete about themselves, to be in chime and to reach a mental physical equilibrium. Men want to be proud of their bodies and outlook. This is why men use products to adorn themselves. Men have become easier about buying products and service to improve or exalt their individual appearance and men move beyond the basic of washing and shaving to envelop more sophisticated products and grooming concepts [31].

Although these trend push men to take care and concern more on themselves, not all men are orienting use skin care products because these products are linked to a female so the consumption of skin care products by men is still labeled "not manly".

Regarding to the above literature review, this study hypothesized that:

$\mathrm{H}_{1}$ : Skin's health attention positively and directly affects purchase decision consumer.

$\mathrm{H}_{2}$ : Body attraction positively and directly affects purchase decision consumer.

$\mathrm{H}_{3}$ : Age and aging process positively and directly affects purchase decision consumer.

$\mathrm{H}_{4}$ : Self-image positively and directly affects purchase decision consumer.

$\mathrm{H}_{5}$ : Cognition of using skin care products positively and directly affects purchase decision consumer.

\section{RESEARCH METHODOLOGY}

\section{A. Questionnaire Design and Data Collection}

The purpose of this study was to investigate personal factors influencing consumer purchase decision of men skin care products. In addition, to test hypotheses about skin's health attention, body attraction, age and aging process, self-image and cognition of using men skin care products in order to predict purchase decision making towards men skin care products.

5-point Likert Scale was used to measure five independent variables and one dependent variable. The questionnaire was designed with two parts, the first part was the personal information and the demographic variables and the second part was measured items of the individual variables and consumer purchase decision. All the measured items were derived from literature in the field of marketing, consumer behavior, and social psychology. Finally, structured survey questionnaires were conveniently distributed to 313 men (from 20 to 50 years old) used skin care products in Ho Chi Minh City, Vietnam.

\section{B. Factor Analysis and Reliability}

Two exploratory factor analyses (EFA) were conducted to evaluate the validity and reliability of the dependent variable and the group of independent variables. The first EFA was conducted for dependent variable of consumer purchase decision with 6 measured items. The KMO index was at $.760>.5$ and the Sig. of Bartlett's test was at .000 $<.05$. There was one component extracted which respectively correspond to the concept of consumer purchase decision in the research model. All 6 items had loading values greater than .5 which illustrated the high correlation between each item and the corresponding extracted component.

TABLE I: SUMMARY OF THE DEPENDENT VARIABLE WITH RELIABILITY COEFFICIENT

\begin{tabular}{lcc}
\hline \multicolumn{1}{c}{ Given Names } & $\begin{array}{c}\text { Number of } \\
\text { Items }\end{array}$ & $\begin{array}{c}\text { Cronbach's } \\
\text { Alpha }\end{array}$ \\
\hline 1. Consumer purchase decision (PDC) & $6^{*}$ & .719 \\
\hline *All items have factor loading $\geq .5$ & & \\
KMO index $=.760$ and Sig. of Bartlett's test $=.000$ & \\
Total variance explained $=41.972 \%$ &
\end{tabular}

Furthermore, the value of Cronbach's Alpha was at .719. It was reasonable to conclude that all of six measured items of the consumer purchase decision dimension were statistically well-related and reliable.

The second EFA was conducted for the group of independent variables, 16 out of 39 items were excluded. 23 items were retained for further analysis. Principle component analysis and Varimax rotation were employed.

TABLE II: SUMMARY OF THE INDEPENDENT VARIABLES WITH RELIABILITY COEFFICIENTS

\begin{tabular}{lcc}
\hline \multicolumn{1}{c}{ Given Names } & $\begin{array}{c}\text { Number } \\
\text { of Items }\end{array}$ & $\begin{array}{c}\text { Cronbach's } \\
\text { Alpha }\end{array}$ \\
\hline 1. Skin's Health Attention (SHA) & $5^{*}$ & .707 \\
2. Body Attraction (BA) & $3^{*}$ & .735 \\
3. Age and Aging Process (AAAP) & $3^{*}$ & .730 \\
4. Self-Image (SI) & $3^{*}$ & .691 \\
5. Cognition of Using Men Skin Care & $3^{*}$ & .699 \\
$\quad$ Products (COUMSCP) & &
\end{tabular}

*All items have factor loadings $\geq .5$

KMO index $=.795$ and Sig. of Bartlett's test $=.000$

Total variance explained $=59.878 \%$

TABLE III: PROFILE OF RESPONDENTS INVOLVED IN THE STUDY

\begin{tabular}{|c|c|c|c|}
\hline & & Frequency & Valid Percentage \\
\hline \multirow{5}{*}{ Age } & 20 to 25 & 105 & $33.5 \%$ \\
\hline & 26 to 35 & 101 & $32.3 \%$ \\
\hline & 36 to 45 & 56 & $17.9 \%$ \\
\hline & 46 to 50 & 51 & $16.3 \%$ \\
\hline & Total & 313 & $100.00 \%$ \\
\hline \multirow{12}{*}{ Career } & Student & 70 & $22.4 \%$ \\
\hline & Staff/Employees & 27 & $8.6 \%$ \\
\hline & Teacher/Faculty & 27 & $8.6 \%$ \\
\hline & Medicine and Pharmacy & 14 & $4.5 \%$ \\
\hline & Armed Forces & 20 & $6.4 \%$ \\
\hline & Small Business & 30 & $9.6 \%$ \\
\hline & Business & 47 & $15 \%$ \\
\hline & Administrative & 10 & $3.2 \%$ \\
\hline & Professional Units & & \\
\hline & Banking & 29 & $9.3 \%$ \\
\hline & Others & 39 & $12.5 \%$ \\
\hline & Total & 313 & $100.00 \%$ \\
\hline \multirow{6}{*}{ Education } & Below High School & 15 & $4.8 \%$ \\
\hline & High School & 40 & $12.8 \%$ \\
\hline & Vocational - College & 73 & $23.3 \%$ \\
\hline & University & 137 & $43.8 \%$ \\
\hline & Above University & 48 & $15.3 \%$ \\
\hline & Total & 313 & $100.00 \%$ \\
\hline \multirow{6}{*}{ Income } & Below 1 millions & 53 & $16.9 \%$ \\
\hline & 1 to below 3 millions & 63 & $20.1 \%$ \\
\hline & 3 to below 6 millions & 77 & $24.6 \%$ \\
\hline & 6 to below 10 millions & 81 & $25.9 \%$ \\
\hline & Above 10 millions & 39 & $12.5 \%$ \\
\hline & Total & 313 & $100.00 \%$ \\
\hline
\end{tabular}

As shown in Table II, the value KMO was at $.795>.5$ and Sig. of Bartlett's test was at $.000<.05$, it means that the factor analysis was appropriate. In addition, there were 5 
factors extracted which respectively correspond to the concepts of Skin's Health Attention, Body Attraction, Age and Aging Process, Self-Image and Cognition of Using Men Skin Care Products in the research model and all items (observed variables) had loading values greater than 0.5 . This illustrated the high correlation between each item and the corresponding extracted component. Moreover, the Crobach's Alpha values of these factors ranged from .691 to .735 , which illustrated the high reliability of the measurement scale for assessing the independent variables.

\section{RESEARCH FINDINGS}

\section{A. Sample Descriptions}

Table III presented the characteristics of the respondents participating in this study. As can be seen from the table, the majority of respondents who have used skin care products were from 20 to 35 years old, accounting for $66 \%$ of the total. They are students or businessmen who have education belong to university or vocational-college. In addition, men using skin care products are people live in affluent families or they have relatively high income (from 3 to above 10 millions), accounting for $70,6 \%$ of the total.

B. Factors Correlating with Consumer Purchase
Decision

TABLE IV: CORRELATIONS BETWEEN VARIABLES

\begin{tabular}{|c|c|c|c|c|c|}
\hline & PURDE & 1 & 2 & 3 & 4 \\
\hline 1. SHA & $.344 *$ & 1 & & & \\
\hline 2. BA & $.264 *$ & $.344 *$ & 1 & & \\
\hline 3. AAAP & $.336^{*}$ & $.362 *$ & $.218^{*}$ & 1 & \\
\hline 4. SI & $.461 *$ & $.293^{*}$ & $.158 *$ & $.344^{*}$ & 1 \\
\hline 5. CUMSCP & $.299 *$ & $.301 *$ & $.225^{*}$ & $.355^{*}$ & $.364^{*}$ \\
\hline Mean & 3.15 & 3.41 & 3.16 & 3.42 & 3.20 \\
\hline SD & .772 & .767 & .967 & .949 & .908 \\
\hline
\end{tabular}

Table IV showed the positive relationships between each personal factor and consumer purchase decision of men. Among these significant relationships, there was the strongest correlation between purchase decision and selfimage $(r=.461, p=.000)$. Besides that, both skin's health attention $(r=.344, p=.000)$ and age and aging process $(r=.336, p=.000)$ had the moderate correlations with purchase decision. Whereas, two remaining factors namely cognition of using men skin care products $(r=.299, p=.000)$ and body attraction $(r=.264, p=.000)$ had the relatively low correlations with purchase decision. This means that consumers who had higher levels of skin's health attention, body attraction, age and aging process, self-image, and cognition of using men skin care products would likely purchase more of men skin care products.

\section{Factors Affecting on Consumer Purchase Decision}

Table $\mathrm{V}$ showed the results of multiple regression testing hypotheses of the research. There were positive and significant impacts of independent variables including skin's health attention, body attraction, age and aging process, self-image on the dependent variable of consumer purchase decision. Standardized beta coefficients illustrated the level of effects of the independent variables on purchase decision (PURDE) in the following order: the first was Self-
Image $(\beta=.335, p<.05)$, the second was Skin's Health Attention $(\beta=.140, p<.05)$, the third was Body Attraction $(\beta=.122, p<.05)$ and the fourth was Age and Aging Process $(\beta=.121, p<.05)$. This means that every 1 standard deviation increasingly change in self-image, or skin's health attention, or body attraction, or age and aging process would lead to an increase in consumer purchase decision of men skin care products of .335 , or .140 , or .122 , or .121 , respectively. Therefore, the regression equation illustrated personal factors affecting consumer purchase decision towards men skin care products could be stated as follows:

$$
\text { PURDE }=0.335 \mathrm{SI}+0.140 \mathrm{SHA}+0.122 \mathrm{BA}+0.121 \mathrm{AAAP}
$$

As $F(5,307)=25.661$ and $p$-value $<.05$, the entire regression equation was statically significant at confidence level of $95 \%$. This means that the above regression equation was deemed to accurately predict the level of consumer purchase decision. It is concluded that the four hypotheses (namely $\mathrm{H}_{1}, \mathrm{H}_{2}, \mathrm{H}_{3}, \mathrm{H}_{4}$ ) of this study were supported at $95 \%$ level of confidence.

TABLE V: COEFFICIENTS BETWEEN DEPENDENT AND INDEPENDENT

\begin{tabular}{ccc}
\multicolumn{3}{c}{$\begin{array}{c}\text { TABLE V: COEFFICIENTS BETWEEN DEPENDENT AND INDEPENDENT } \\
\text { VARIABLES }\end{array}$} \\
\hline $\begin{array}{c}\text { Standardized } \\
\text { Coefficients } \\
\text { (Beta) }\end{array}$ & $\begin{array}{c}\text { Correlation } \\
\text { (Part) }\end{array}$ \\
\hline SHA & $.140^{* *}$ & .344 \\
\hline BA & $.122^{* *}$ & .264 \\
\hline AAAP & $.121^{* *}$ & .336 \\
\hline SI & $.335^{* *}$ & .461 \\
\hline CUMSCP & .064 & .299 \\
\hline - . Predictors: SHA, BA, AAAP, SI, CUMSCP & \\
- Dependent Variable: PURDE & \\
- ANOVA: $F=25.661$, Sig. $=.000$ & \\
- Model summary: Adjusted $R^{2}=.283$ &
\end{tabular}

\section{DISCUSSIONS AND RECOMMENDATIONS}

During the study, all analysis steps were aimed at serving the answer for research questions. The analysis of these indices strictly controlled in the purpose and scope of the study. The empirical results showed the levels of each factor that had the impacts on consumer purchase decision. Hence, the study would give some recommendations to help increase the development for the companies in the industry towards men skin care products.

With the highest value of Beta $(\beta=.335)$, the "self-image" factor was the most influential factor which had the strongest impacts on the level of consumer purchase decision. According to [32], self is "the totality of a person's feelings about himself to serve as an object". It was like turning a person (the self) and the actual assessment that he (she) is who and what is what [33]. In Ho Chi Minh City, a dynamic city with jobs and modern activities, the essential thing is appearance. Therefore, men understand clearly about that and they always want to refresh the self-image to better serve for their job. Besides that, the development of self-image is one of many top concerns for young people in finding girlfriends or to improve family relationships. This promotes the selection process to purchase skin care products for men. Thus, cosmetics companies in general and skin care products companies in particular should focus on 
self-image of men to focus on exploiting and developing the product as well as marketing strategies for the company. This is one advantage for long-term product development.

Although the three factors of "skin's health attention", "body attraction", and "age and aging process" had the moderate influences on the consumer purchase decisions $(\beta$ $=.140, \beta=.122$ and $\beta=.121$, respectively), these factors were evaluated at the moderate levels which were still far behind the desired one. This illustrated that men did not care too much about their health, attraction and the decrease appearance due to age and aging process. For this problem, the skin care products market should develop the advertising strategies as well as the supplying of the knowledge on using skin care products to improve purchase decision making of men. However, these factors are not the main sides to focus on exploiting products. Therefore, investors and companies should concern more about the factor had the strongest influences on using skin care products.

In the research, "Cognition of Using Men Skin Care Products" factor was deleted. It means that this factor is not significant on consumer purchase decisions. This concluded that men are still men, although they had the change in their minds about beauty care industry because skin care products are not seen as something that has been launched only for women anymore. However, they still are fearful about using skin care product can be seen as be labeled as 'gay'. In addition, almost men use skin care products to improve their appearance, not to take care for their health. Thus, it is not the necessary factor to focus on produce skin care products for companies.

\section{CONCLUSIONS}

This study contributed to a common understanding of purchase decision of men using skin care products in Vietnam, in the context of male skin care products market is growing but not much research has focused on the issue purchase decision of male subjects.

Research has contributed to model personal factors of consumer affect purchase decision men, corresponding to skin care product is a cosmetic product. From the synthesis of theoretical models and based on previous studies, the research have proposed a research model for individual variables. Based on the results of data analysis process, the research has identified personal factors that affect purchase decision of men skin care products on the scope of Ho Chi Minh City in particular and Vietnam in general. Research also contributes to enforcement of the scale for individual variables related to the consumption of skin care products.

In conclusion, although the research is still limited, but the results will contribute to providing a basis for decision making for the skin care products company, while it is useful for marketers to be able to find solutions for marketing impact and promote purchase decision towards men skin care products in particular and cosmetics for men in general.

\section{REFERENCES}

[1] N. Souiden and M. Diagne, "Canadian and French men's consumption of cosmetics: A comparison of their attitudes and motivations," Journal of Consumer Marketing, vol. 26, no. 2, pp. 97 $109,2009$.
[2] D. V. K. Nair et al., "A study on purchase pattern of cosmetic among consumers in Kerala," in Proc. International Marketing Conference on Marketing \& Society, Singapore: M.A.K, 2007.

[3] Data Panel, Europe, TGI Europa, 2002.

[4] P. Kotler and S. J. Levy, "Broadening the concept of marketing," Journal of Marketing, vol. 33, no. 1, pp. 10-15, 1969.

[5] L. L. David and J. D. B. Albert, Consumer Behaviour, McGraw Hill, New Delhi, 2002.

[6] L. G. Schiffman and L. L. Kanuk, Consumer Behavior, 9th ed. Upper Saddle River, N.J.: Pearson Prentice Hall, London, 2007.

[7] R. L. Sandhusen, Marketing, Barron's Business Review Series, 3rd ed. New York, NY: Barron's Educational Series, 2000.

[8] J. F. Engel, R. D. Blackwell, and P. W. Miniard, Consumer Behavior, Florida: The Dryden Press, 1995.

[9] S. R. Hursh, "Economic concepts for the analysis of behavior," Journal of the Experimental Analysis of Behavior, vol. 54, pp. 219238,1980

[10] J. J. Kacen and J. A. Lee, "The influence of culture on consumer impulsive buying behavior," Journal of Consumer Psychology, vol. 12, no. 2, pp. 163-176, 2002.

[11] S. Talluri, "A buyer-seller game model for selection and negotiation of purchasing bids," European Journal of Operational Research, vol. 143, pp. 171-180, 2002.

[12] S. Tara, What is Consumer Behavior in Marketing?-Factors, Model \& Definition. [Online]. Available: http://study.com/academy/lesson/what-is-consumer-behavior-inmarketing-factors-model-definition.html

[13] M. Rosenberg, Conceiving the Self, New York, NY: Basic Books, 1979.

[14] H. Dittmar, The Social Psychology of Material Possessions: To have Is to Be, Hemel Hempstead: Harvester Wheatsheaf \& New York: St. Martin's Press, 1992.

[15] T. B. Rogers, N. A. Kuiper, and W. S. Kirker, "Self-reference and the encoding of personal information," Journal of Personality and Social Psychology, vol. 35, pp. 677-688, 1977.

[16] R. A. Wicklund and P. M. Gollwitzer, Symbolic Self-Completion, Hillsdale, NJ: Erlbaum, 1982.

[17] P. Kotler, "Consumer markets and consumer buyer behavior," Principles of Marketing, ch. 5, pp. 35-137, 2005.

[18] A. A. Conseur, Factors Influencing the Emergence of the Metrosexual, Dean of the Graduate School, University of Georgia, 2004.

[19] A. A. Saadi and R. Mohammad, Consumer Behavior (External and Internal Factors), Tehran: Press Alliance - Aylar, p. 192, 2011

[20] R. M. Taheri, R. Mosayeb, G. A. Azizi, and N. S. Mohsen, "The effect of individual factors on consumers' purchasing decisions," Journal of Basic and Applied Scientific Research, vol. 3, no. 1, p. $1150,2013$.

[21] P. K. Hatemi, C. A. Klofstad, and R. McDermott, "The dating preferences of liberals and conservatives," Political Behavior, 2014.

[22] P. K. Hatemi, R. McDermott, and D. Tingley, "Assortative mating on ideology could operate through olfactory cues," American Journal of Political Science, 2014.

[23] H. Meena. (July 20, 2010). Attractive people paid better at work, get more attention from their bosses: Report. NY Daily News. [Online]. Available: http://www.nydailynews.com/news/money/attractivepeople-paid-better-work-attention-bosses-report-article-1.466980

[24] T. Higgins, "Self-discrepancy: A theory relating self to affect," Psychological Review, vol. 94, pp. 319-340, 1987.

[25] D. Helga and D. John, "Self-image - is it in the bag? A qualitative comparison between 'ordinary' and 'excessive' consumers," Journal of Economic Psychology, vol. 21, no. 2000, pp. 109-142, Sep. 10, 1999.

[26] G. R. Gina. (April 3, 2013). 4 health problems your skin can help you detect. [Online]. Available: http://www.nextavenue.org/article/201304/4-health-problems-your-skin-can-help-you-detect

[27] D. Asch and B. Wolfe, New Economy - New Competition, the Rise of the Consumer? Palgrave, New York, 2001.

[28] N. Hanna and R. Wozniak, Consumer Behavior: An Applied Approach, Upper Saddle Revier. NJ: Prentice-Hall, Inc, 2001.

[29] D. L. Hawkins, D. Mothersbaugh, and R. J. Best, Consumer Behavior: Building Marketing Strategy, New York, McGraw-Hill, 2007.

[30] L. S. A. L. Maria, T. S. A. B. Maria, and C. E. Maria, "Factors that affect decision making: gender and age differences," International Journal of Psychology and Psychological Therapy, vol. 7, no. 3, pp. 381-391, 2007.

[31] M. Imogen, "Men's grooming: Brands drive growth," GCI Magazine, pp. 39-40, 2005. 
[32] D. A. Hershey and J. A. Wilson, "Age differences in performance awareness on a complex financial decision-making task," Experimental Aging Research, vol. 23, pp. 257-273, 1997.

[33] Y. Nakajima and M. Hotta, "A developmental study of cognitive processes in decision-making: Information-searching as a function of task complexity," Psychological Reports, vol. 64, pp. 27-40, 1989.

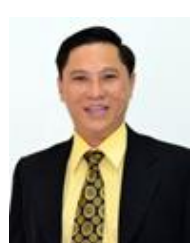

Mai Ngoc Khuong is a lecturer and researcher of School of Business, International University, VNUHCM. He has a bachelor degree in tourism and hospitality management, master of science degree in leisure, tourism and environment at Wageningen
University, the Netherlands, and PhD degree in development management at School of Public Administration of National Institute of Development Administration (NIDA), Bangkok, Thailand.

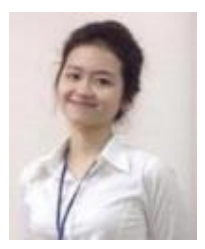

Hoang Thi My Duyen is a research assistant of School of Business Administration, International University, Vietnam National University, Ho Chi Minh. She has bachelor degree in business management. And her research interest is consumer/tourist behaviour. 